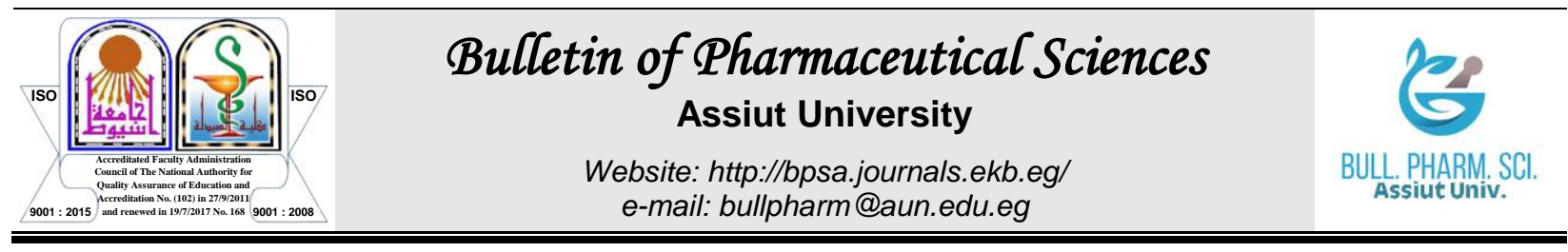

\title{
A COMPARATIVE STUDY ON THE EFFECTS OF THE FENUGREEK SEEDS' POWDER AND ITS AQUEOUS AND OIL EXTRACTS ON THE MALE REPRODUCTIVE SYSTEM IN ALBINO RATS
}

\author{
Azza Badry $^{1 *}$, Aaml Abou Elghait ${ }^{2,3}$, Amira Abo-youssef ${ }^{4}$, Nada S. Abdelwahab ${ }^{5}$ and Hassan \\ Helaly $^{6}$ \\ ${ }^{1}$ Health Affairs Directorate, Ministry of Health and Population, Assuit, Egypt \\ ${ }^{2}$ Histology Department, Faculty of Medicine, Assiut University, Assiut, Egypt \\ ${ }^{3}$ Histology Department, Sphinx University, Assiut, Egypt \\ ${ }^{4}$ Pharmacology and Toxicology Department, Faculty of Pharmacy, Beni-suef University, Beni- \\ suef, Egypt \\ ${ }^{5}$ Pharmaceutical Analytical chemistry, Faculty of Pharmacy, Beni-suef University, Beni-suef, \\ Egypt \\ ${ }^{6}$ Pharmacology and Toxicology Department, Faculty of Medicine, Al Azhar University, Assuit, \\ Egypt
}

Trigonella foenum-graecum has long been used as a medicinal plant for the treatment of nutritional, metabolic and sexual dysfunction in both genders.Objectives: our study aimed at evaluating the possible effects of different dosage forms of fenugreek seeds on the male reproductive system in animals.Methods: In a randomized controlled study, 40 male albino rats weighing 180 to $260 \mathrm{gm}$. were equally divided into four groups, one control and the other three groups were treated by the administration of either powder $(200 \mathrm{mg} / \mathrm{kg})$, aqueous $(500 \mathrm{mg} / \mathrm{ml})$ or oily extract $(200 \mathrm{mg} / \mathrm{ml})$ forms, 3 times weekly for 8 weeks. Serum luteinizing hormone, follicle-stimulating hormone, prolactin, estrogen, progesterone, and testosterone levels were evaluated, as well as histological examination \& sperm analysis. Results: Concerning the oily extract dosage form, a highly significant decrease $(P<0.01)$ in FSH was recorded in comparison to other groups. LH was reduced significantly $(P<0.05)$ in the three treated comparative groups. However, progesterone and estrogen levels were significantly increased $(P<0.05)$ after the administration of the oily form. Testosterone level was detected higher only in the aqueous form with a significant increase $(p<0.05)$ in sperm count, unlike the other 2 forms. The results have revealed a significant $(p<0.05)$ decrease in all sperm evaluated parameters as well as destructions in testicular tissues after the administration of the oily form. Conclusion: The effect of the aqueous form on the male hormonal levels have been significantly noticed with remarkable changes in the sperm vitality as well the sperm count. The oily form showed a devastating action on all the evaluated parameters.

\section{INTRODUCTION}

Fenugreek is one of the oldest medicinal plants used for its medicinal benefits around the world ${ }^{1}$. Fenugreek or Trigonella foenumgraecum is a fragrant herb that belongs to the family Fabaceae and has been grown extensively in most of the world ${ }^{2}$. However, fenugreek is specially cultivated in the Indian subcontinent, South Asia, the Middle East, some African countries, Mediterranean Europe,
China, Australia, the USA, Canada and Argentina $^{2 \& 3}$. Fenugreek is a clover-like herb in which the most important part is the seeds. Its seeds smell and taste like maple syrup and have been used in industrial, cooking and medicinal products $^{4 \& 5}$.

Trigonella foenu-graecum has been widely used in folk medicine and have a wide range of pharmacological actions: as an antihypertensive, anti-hypercholesterolemic ${ }^{4}$, 
gastroprotective activity ${ }^{6}$, appetite stimulation ${ }^{7}$, antioxidant action, improving cardiac function in patients with coronary artery diseases, as hormonal replacement therapy in postmenopausal symptoms, and in male sexual dysfunction ${ }^{11 \& 18}$.

Fenugreek contains a number of active constituents that were used since thousands of years ago in folk medicine. These include mucilage, the alkaloid hormone trigonelline, 4hydroxyisoleucine, galactomannan, luteolin, sotolon, diosgenin, protodioscin, flavonoids, steroidal saponins, vitamins, minerals, and phenolic acids ${ }^{8 \& 9}$. Galactomannan is a soluble fiber (carbohydrate) which represents $45-60 \%$ of the fenugreek seed's active constituents ${ }^{10}$.

Steroidal saponins (Diosgenin and yamogenin) have been well known for their estrogenic effects such as binding to E2 receptors and persuading of E2 expression genes. In addition, few studies have mentioned the ability of these saponins to positively influence the male sexual function ${ }^{11 \& 12}$.

In addition, diosgenin is a famous precursor used for more than $60 \%$ of the commercially available cortisone, pregnenolone, progesterone, and other steroids. It is mainly used as a stimulator for growth hormone from the pituitary ${ }^{8}$. Diosgenin is a sapogenin steroid which is found in many plants as wild Yam roots and in fenugreek ${ }^{13}$. It is known as a relief for post-menopausal symptoms ${ }^{14}$. In a study evaluating the effect of fenugreek on ovariectomized rats, Benghuzzi and colleagues reported that body weight and spleen weights were both increased in ovariectomized rats in comparison to control. An increase in the cortical and medullary areas of the ovariectomized rats were exhibited in the histopathological samples of the adrenal gland in comparison to those with the diosgenin treated animals ${ }^{15}$.

Another study evaluating the effect of diosgenin on ovarian cell of farm animals, revealed an increase in proliferation, apoptosis in the cytoplasm, testosterone (T), estradiol (E2), and progesterone (P4) release as an impact of diosgenin dose administration $(0,1$, 10 , or $100 \mu \mathrm{g} / \mathrm{mL}$ medium). Moreover, the study has revealed an inhibition in pig's P4 and a stimulation of $\mathrm{T}$ release. Rabbit ovarian cells showed a stimulation in both P4 and IGF-I. The study has justified the change in the effect between pigs and rabbits as species-specific manner ${ }^{16}$.

In another study, the effect of Trigonella foenum-graecum seed on sex hormones and sexual function in healthy menstruating women was assessed, in a dose of $600 \mathrm{mg} /$ day or placebo over two menstrual cycles. Dehydroepiandrosterone sulfate, progesterone, androstenedione, total and free testosterone, estradiol (E2), luteinizing hormone (LH), follicle stimulating hormone (FSH), sex hormone binding globulin as well as cholesterol levels were measured at baseline and after 8 weeks. The study revealed a significant elevation in free testosterone and E2 in the active group as well as an increase in libido in comparison with the control group ${ }^{17}$.

Additionally, a systematic review was conducted for assessing fenugreek extract has revealed that it has a substantial impact on serum total testosterone level in men ${ }^{18}$.

Moreover, a study was designed to assess the effect of Testofen (standardized Trigonella foenum-graecum extract) on male libido. A double blind randomized controlled study was conducted on humans. Testofen exhibited an overall positive effect on physiological features of libido. An increase in the sexual arousal and orgasm were observed. Testofen showed a remarkable impact on self-reported satisfaction with muscle strength, libido, and energy. Both serum prolactin and testosterone levels were preserved within normal range ${ }^{12}$.

In addition, a study evaluating the administration of $600 \mathrm{mg} /$ day of testofen for 12 weeks in men revealed an increase in the number of morning erections and rate of sexual activity. The study has detected an increase in total serum testosterone and free testosterone compared to placebo after 12 weeks of active treatment in healthy middle-aged and elder $\operatorname{men}^{17}$.

\section{Accordingly}

This study aimed at evaluating the possible effects of fenugreek seeds' different dosage forms (powder, aqueous and oily extracts) on the male reproductive systems using albino rats as experimental animals. 


\section{MATERIALS AND METHODS}

\section{Animals}

Animals used, were purchased from the Animal Care House, Faculty of Medicine, Assiut University. The study was approved by the Ethics Board of Beni Suef University. This study was conducted in accordance with the ethical procedures and policies approved by the Animal Care and Use Committee of Faculty of Medicine, Assiut University, Egypt.

\section{Kits}

All kits used were produced by Autobio Diagnostic co., LTD No.87 Jingbie Yi Road, China. Kits were used for hormonal assay

\section{Fenugreek seed powder and its aqueous \& oil extracts}

Commercial Trigonella seeds were used.

The aqueous extract was prepared using a simple traditional decoction method. The seeds $(50 \mathrm{gm}$.) were soaked in $100 \mathrm{ml}$ distilled water and allowed to biol for 5 minutes. Then, subjected to a double filtration procedure, to recover the aqueous extract $(450 \mathrm{mg} / \mathrm{ml})$, which was preserved at $4^{\circ} \mathrm{C}$ until use ${ }^{19}$.

Fenugreek oil in a concentration of 200 $\mathrm{mg} / \mathrm{ml}$, was purchased from Cap Pharm for Extracting Natural Oils \& Herbs, Cairo, Egypt.

For the preparation of fenugreek powder, $50 \mathrm{gm}$. of the seeds were washed with tap water and then air dried under shade. The seeds were then crushed and powdered by electronic grinder and kept at room temperature until used.

\section{Experimental animals and study design}

This study was conducted on 40 male albino rats weighing 180 to $260 \mathrm{gm}$. were used. Animals were housed in stainless cages and kept in suitable environmental conditions of 20 - $25{ }^{\circ} \mathrm{C}$ air-conditioned room and daily photoperiod of 12 hours. Food and water were made available throughout the day, ad libitum. Animals were equally divided into four groups, one control and other three treated ones, as follows :

- Group 1 Control group, received distilled water for 8 weeks

- Group 2 Powder treated group, received the powder form of fenugreek seeds $(200 \mathrm{mg} / \mathrm{Kg}$ body weight, 3 times per week for 8 weeks) added to animals' prepared food.
- Group 3 Aqueous extract treated group, received the aqueous extract $(500 \mathrm{mg} / \mathrm{ml})$ form of fenugreek seeds $(2 \mathrm{ml}, 3$ times per week for 8 weeks) orally by a stomach tube.

- Group 4 Oil extract treated group, received the oil extract $(200 \mathrm{mg} / \mathrm{ml})$ form of fenugreek seeds $(2 \mathrm{ml}, 3$ times per week for 8 weeks) orally by a stomach tube.

\section{Blood sample collection}

At the end of the study period, blood samples were collected from the retro-orbital plexus. Serum was separated by centrifugation at $2500 \mathrm{rpm}$, for $15 \mathrm{~min}$. at room temperature. The sera were then stored at $-18{ }^{\circ} \mathrm{C}$ until time of analysis.

\section{Hormonal assay}

Estimation of serum luteinizing hormone (LH), follicle-stimulating hormone (FSH), prolactin, estrogen $(\mathrm{E} 2)$, progesterone $(\mathrm{P})$ and testosterone $(\mathrm{T})$ levels were estimated by using standard assay kits.

\section{Sperm collection and evaluation}

At the end of the study, animals were sacrificed under anesthesia and the male reproductive organs were carefully dissected out

\section{Sperm count (sperms/ ml)}

The testis and epididymis excised from the rats were minced into $20 \mathrm{ml}$ of $0.9 \% \mathrm{NaCl}$. The cell count was carried out directly by a microscope counting, using a Malassez cell and was expressed in million $/ \mathrm{ml}$ of the sperm suspension $^{20}$.

\section{Sperm Motility}

The sperm progressive motility (SPM) was estimated by evaluating 4 fields of sperm droplet under a cover-slip on a warm glass slide under light microscopy $(\times 40)^{21}$.

\section{$\%$ Sperm vitality}

For the assessment of live and dead sperms, Chemineau et al method was used ${ }^{22}$. By mixing one drop of sperm suspension with one drop of Eosin-Nigrosin stain on a glass slide. Live sperms repel the vital stain (EosinNigrosin) while the dead sperms absorb the dye . 
Sperms vitality was calculated by using the following equation

Percentage of dead sperms $=$ (No. of live sperms / Total No. of Sperms) $\times 100$.

\section{Histological studies on testis}

At the end of the study, animals were sacrificed and the male reproductive organs were carefully dissected out.

\section{Light microscopic examination}

testes specimens from all groups were taken, and fixed in bouin for 16-18 hrs., washed by $70 \%$ alcohol, dehydrated by ascending grades of alcohols and embedded in paraffin, sectioned at $(5 \mu \mathrm{m})$ thickness by a microtome and stained with the following stains: general $\mathrm{H}$ \& $\mathrm{E}$ stain for general histological examination.

\section{Statistical analysis}

The statistical package (SPSS) program, version 23 was used for data analysis. Data were expressed as Mean \pm SEM. Data were analyzed by ANOVA, and confidence limit was accepted at $95 \%$ and $99 \%$ interval.

\section{RESULTS AND DISCUSSION}

\section{Results}

Effects of fenugreek seeds different dosage forms (Powder, aqueous and oil extracts) on hormonal levels

Comparison regarding hormonal levels in the three different dosage forms of fenugreek namely; powder, aqueous and oily forms has revealed a significant decrease of FSH hormone by $34.5 \%$ in the oily dosage form, followed by a slightly comparable reduction in both the aqueous and powder forms in comparison with the control group by $24.2 \%$ and $16.2 \%$; respectively. LH hormonal levels were reduced significantly in the three groups. Progesterone level was remarkably elevated $(p<0.001)$ in the oily form by $222 \%$, followed by the powder form with a $140 \%$ elevation and finally, a $129 \%$ elevation in the aqueous form compared to the control group. Similarly, E2 was elevated in the oily treated group when compared to the control group with high significant increase $(p<0.001)$. On the contrary, the powder form has reduced the release of E2 by $10 \%$ in comparison to the control. Testosterone levels were detected higher solely in the aqueous form by $34.3 \%$ ( $<$ < 0.001 ) unlike the other 2 forms. In addition, no significant change was detected in prolactin level in all groups compared to the control group as shown in table (1).

Table 1: Assayed hormonal levels in the 3 comparative groups $(\mathrm{N}=10)$

\begin{tabular}{|c|c|c|c|c|}
\hline Parameters & Control & $\begin{array}{c}\text { Fenugreek } \\
\text { powder }\end{array}$ & $\begin{array}{c}\text { Fenugreek aqueous } \\
\text { extract }\end{array}$ & $\begin{array}{c}\text { Fenugreek oil } \\
\text { extract }\end{array}$ \\
\hline FSH (ng/ml) & $2.9 \pm 0.1$ & $2.4 \pm 0.08$ & $2.6 \pm 0.15$ & $1.9 \pm 0.14^{* *}$ \\
\hline$\%$ of change & & $-16.2 \%$ & $-13.8 \%$ & $-34.5 \%$ \\
\hline LH (ng/ml) & $1.7 \pm 0.1$ & $1.45 \pm 0.1^{*}$ & $1.3 \pm 0.12 *$ & $1.4 \pm 0.12 *$ \\
\hline$\%$ of change & & $-14.7 \%$ & $-23.5 \%$ & $-18 \%$ \\
\hline Progesterone (ng/ml) & $2.7 \pm 0.4$ & $3.8 \pm 0.18 *$ & $3.5 \pm 0.3^{*}$ & $6 \pm 0.5 * *$ \\
\hline$\%$ of change & & $+140 \%$ & $+129 \%$ & $+222 \%$ \\
\hline E2 (pg/ml) & $20 \pm 1.1$ & $18 \pm 0.67$ & $20.8 \pm 1.47$ & $30 \pm 2.5^{* *}$ \\
\hline$\%$ of change & & $-10 \%$ & $+4 \%$ & $+50 \%$ \\
\hline Prolactin $(\mu \mathrm{IU} / \mathrm{ml})$ & $2.1 \pm 0.15$ & $1.9 \pm 0.1$ & $1.9 \pm 0.05$ & $2.0 \pm 0.1$ \\
\hline$\%$ of change & & $-9.5 \%$ & $-9.5 \%$ & $-4.7 \%$ \\
\hline \multirow{2}{*}{$\begin{array}{c}\text { Testosterone }(\mu \mathrm{u} / \mathrm{dl}) \\
\% \text { of change }\end{array}$} & \multirow[t]{2}{*}{$3.2 \pm 0.18$} & $2.3 \pm 0.2 *$ & $4.3 \pm 0.3 * *$ & $2.1 \pm 0.2 * *$ \\
\hline & & $-29.1 \%$ & $+34.5 \%$ & $-34.4 \%$ \\
\hline
\end{tabular}

Values represent mean \pm SE (standard error). ( $\mathrm{p}^{* *}<0.01, \mathrm{p}^{*}<0.05$, as compared to control group). E2: Estogen, FSH: Follicle Stimulating hormone, LH: Luteinizing hormone 
Histopathological changes in testicles regarding the 3 comparative groups Group I: Control one

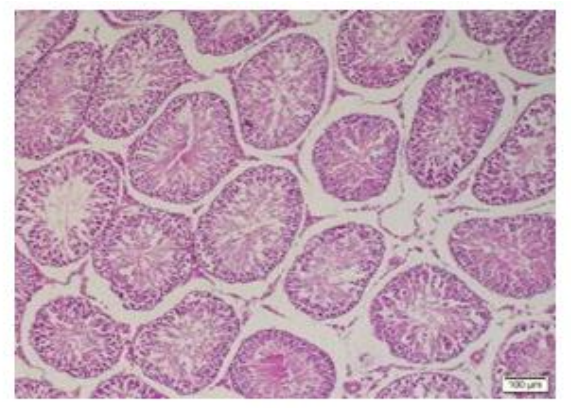

Fig. 1.a

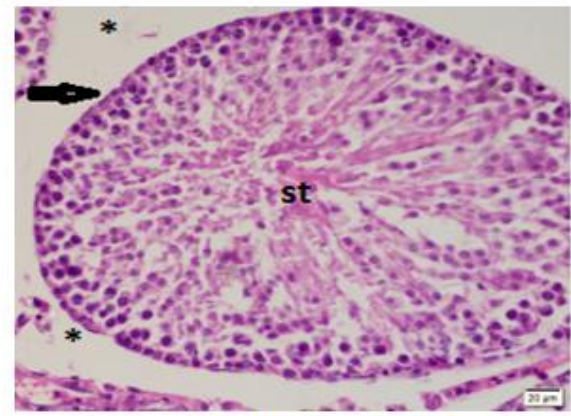

Fig. 1.c

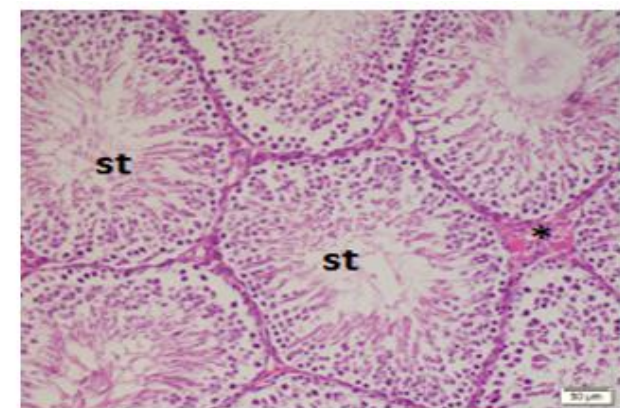

Fig. 1.b

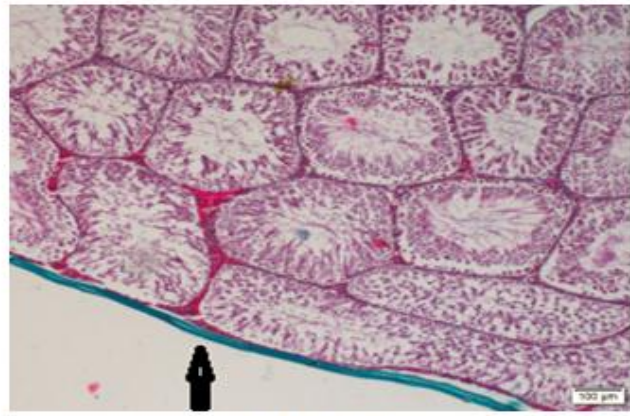

Fig. 1.d

Fig. 1: Histological appearance of normal seminiferous tubules in the control group

Light microscopic examination demonstrated that the control albino rats' testes formed of groups of seminiferous tubules having regular rounded or oval shape, and surrounded by regular basement membrane. Each tubule was lined by germinal epithelium at different stages of development and supporting Sertoli cell, (Fig. 1.a)

All the cells of the spermatogenic series such as spermatogonia, spermatocyte, spermatids and spermatozoa, and sertoli cells could be identified in the tubules. The lumen could easily be delineated in almost all the tubules and majority of them was occupied by mature spermatozoa, (Fig 1.b).

In between the tubules, the interstitial tissue contains blood vessels and interstitial cells of Leydig. Either arranged single or in clumps, the cells appear polyhedral in shape with large rounded or oval vesicular nuclei and pale finely vacuolated cytoplasm (Fig. 1.c).

In group (I), examination of Masson trichrome stained sections revealed collagen fibers with normal distribution in the capsule. Few collagen fiber depositions in the seminiferous tubules basement membranes and around blood vessels walls, (Fig. 1.d).
Group II \& III: powder and aqueous treated groups : (Fig. $2 \& 3$ )

In these groups, the majority of seminiferous tubules appear more or less regular in outline. They showed nearly normal architecture with the appearance of the germinal cell population including different types of germ cell (Fig. 2.a) \& (Fig. 3.a). But some tubules showed some degenerative effects in the form of irregularity of the basement membrane, multiple empty spaces, residual cytoplasmtic droplets and few degenerated cells [Fig. 2.(b \& c)] \& [Fig. 3.(b \& c)].

Regarding the interstitial tissue, it appeared nearly similar to the control group except for the presence of some Leydig cells that declare some abnormalities in the form of irregular nucleus with some areas of chromatin condensation, [Fig. 2.(b \& c)] \& [Fig. 3.(b \& c)].

In Masson trichrome stain, group (II) \& (III) showed thick collagen fiber distributions in the capsule. Also, the distribution of collagen fibers around the blood vessels and in the basement membrane of seminiferous tubules were slightly thickened than normal (Fig. 2.d) \& (Fig. 3.d). 


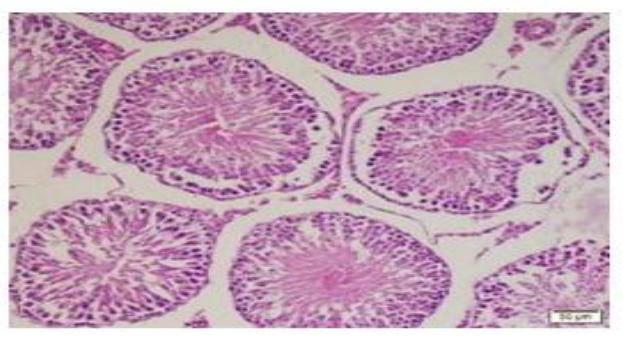

Fig. 2.a

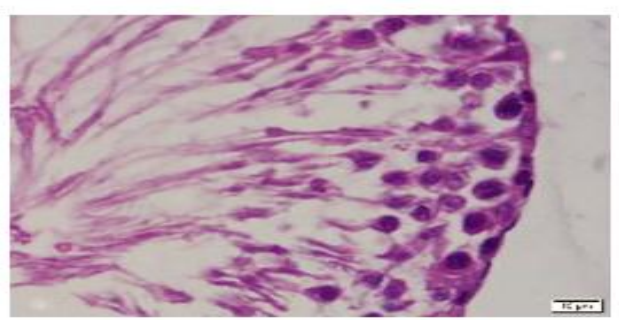

Fig. 2.c

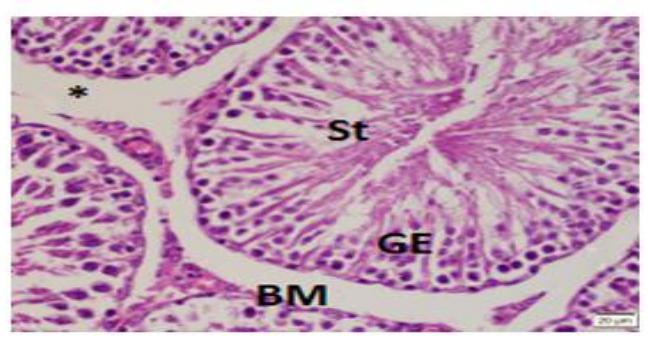

Fig. 2.b

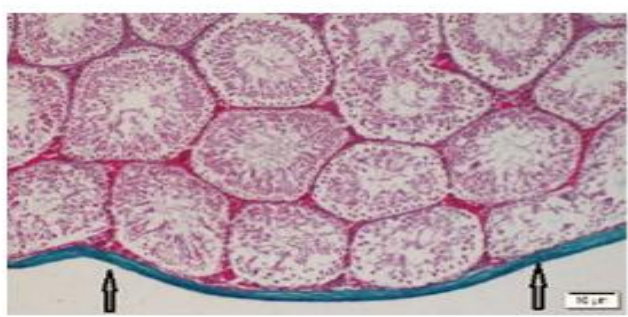

Fig. 2.d

Fig. 2: Histological changes in seminiferous tubules in fenugreek seeds powder treated group

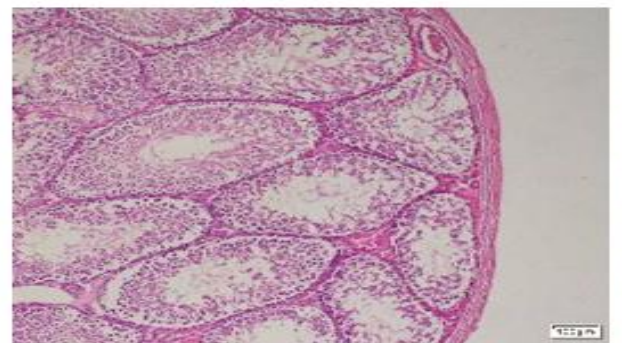

Fig. 3.a

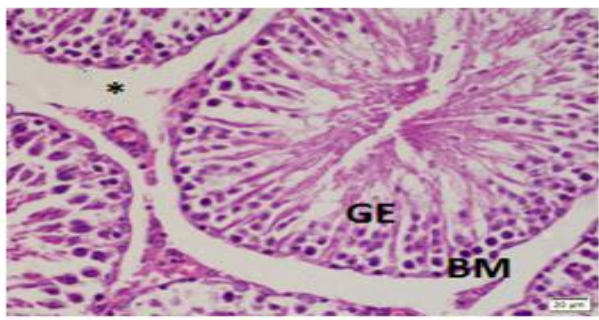

Fig. 3.c

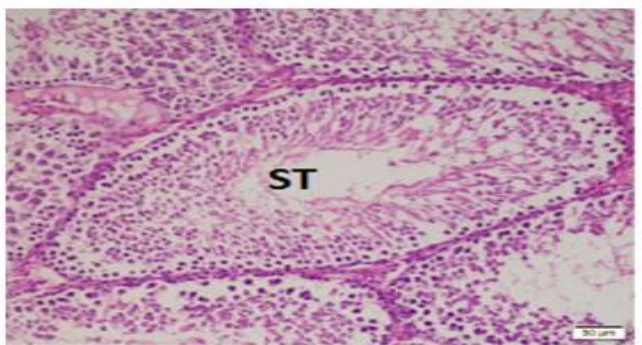

Fig. 3.b

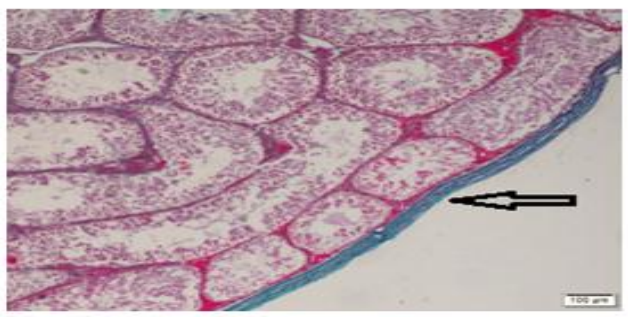

Fig. 3.d

Fig. 3: Histological changes in seminiferous tubules in fenugreek seeds aqueous extract treated animals

\section{Group IV: Oil extract treated group (Fig. 1)}

In comparison to the control group, light microscopic examination of the testes revealed severe degeneration and disruption of the integrity of the tubules. Many tubules revealed multiple vacuolation and their germinal epithelium appeared dissociated from each other. The basement membrane is severely interrupted at multiple areas. Sertoli cells are completely destructed and replaced by swollen degenerated apoptotic cells. There are no noticeable mature sperms within many tubules. Some tubules appear severely atrophied and only occupied by degenerated destructed cells (Fig. 4.a).

The interstitial tissue examination exhibited obvious changes, it showed thickened dilated blood vessel. Most of the Leydig cells are destructed leaving multiple vacuoles clearly seen within most of the sections, (Fig. 4.b\&c).

In group 4, the sections stained with Masson trichrome stain revealed dense collagen fibers deposition in the capsule and around blood vessels, as well as the basement membrane of most seminiferous tubules (Fig. 4.d). 


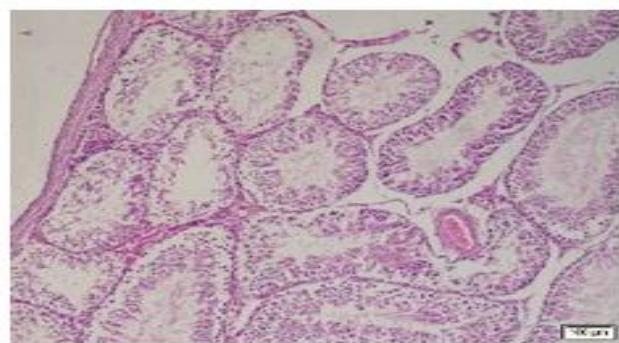

Fig. 4.a

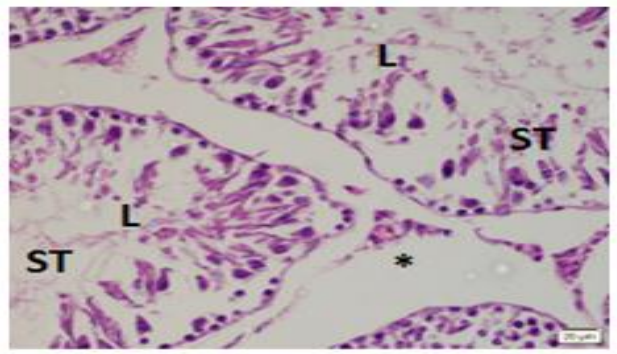

Fig. 4.c

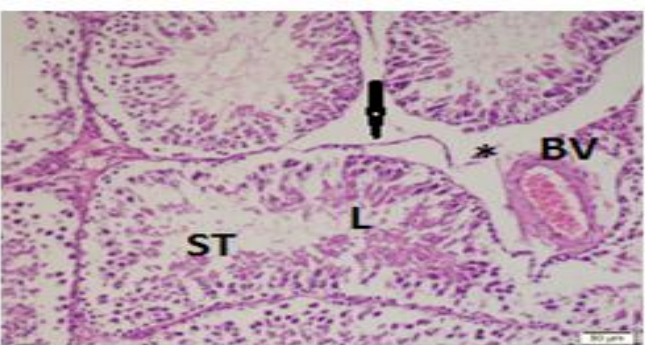

Fig. 4.b

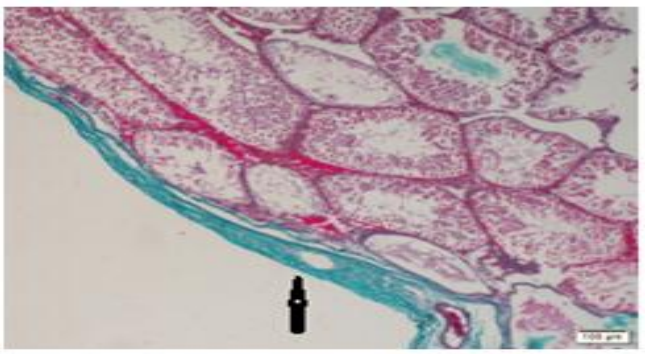

Fig. 4.d

Fig. 4: Histological changes in seminiferous tubules in fenugreek seeds oil extract treated group

Effects of fenugreek seeds different dosage forms on sperm parameters Sperm count

As shown in table (2), the results obtained, revealed a significant $(\mathrm{p}<0.05)$ decrease in the sperm count in both the oil extract and powder treated groups by $(41.7 \%$ \& $33.3 \%$ respectively), while a significant increase ( $\mathrm{p}<$ 0.05 ) by $25 \%$ was detected in the aqueous treated group as compared to the control one.
Sperms viability (\%)

The effects of fenugreek different dosage forms (powder, aqueous and oil extracts) on the percentage of live sperms have been pointed in Table (3) \& Fig. 5. There was a significant decrease $(\mathrm{p}<0.05)$ in the percentages of live sperms in both, the oil extract and powder treated groups as compared to the control one. Whereas, no significant change was detected with the aqueous extract treated group as compared to the control group.

Table 2: Sperms count in the control and treated groups $(\mathrm{N}=10)$

\begin{tabular}{|c|c|c|c|c|}
\hline Parameters & Control & $\begin{array}{c}\text { Fenugreek } \\
\text { powder }\end{array}$ & $\begin{array}{c}\text { Fenugreek } \\
\text { aqueous extract }\end{array}$ & Fenugreek oil \\
\hline $\begin{array}{c}\text { Sperm } \\
\text { count*10 } / \mathbf{m l}\end{array}$ & 60 & 40 & 75 & 35 \\
\% of change & & $-33.3 \%$ & $+25 \%$ & $-41.7 \%$ \\
\hline
\end{tabular}

Values represent $(\mathrm{sperm} / \mathrm{ml})$

Table (3): Sperms vitality in the control and treated groups $(\mathrm{N}=10)$

\begin{tabular}{||l|c|c|c|c|}
\hline $\begin{array}{c}\text { Parameter } \\
\text { s }\end{array}$ & Control & $\begin{array}{c}\text { Fenugreek } \\
\text { powder }\end{array}$ & $\begin{array}{c}\text { Fenugreek aqueous } \\
\text { extract }\end{array}$ & $\begin{array}{c}\text { Fenugreek } \\
\text { oil }\end{array}$ \\
\hline $\begin{array}{l}\text { Sperm } \\
\text { vitality }\end{array}$ & $75.3 \pm 2.1$ & $67.1 \pm 2.4^{*}$ & $76.4 \pm 1.7$ & $43.7 \pm 1.4^{* *}$ \\
$\begin{array}{l}\text { (No. of live } \\
\text { sperm) }\end{array}$ & & & & \\
\hline
\end{tabular}

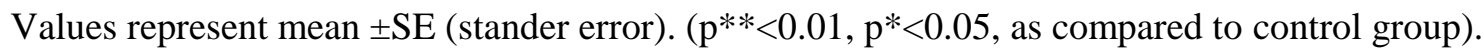




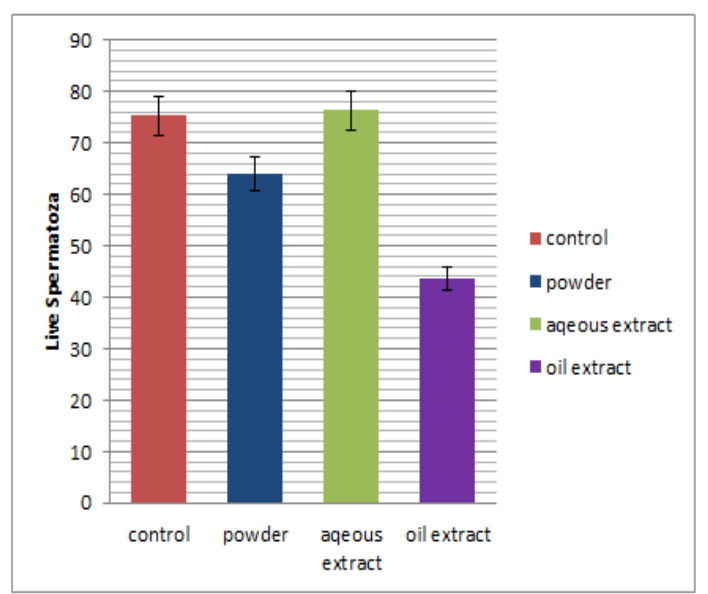

Fig. 5: Percentage of Live spermatozoa after administration of fenugreek seeds different forms (powder, aqueous \& oil extracts) after 60 days treatment.

\section{Sperm motility}

As shown in Fig. 6: administration of fenugreek seeds aqueous extract and powder did not affect sperm motility in treated animals compared to the control group. While the percentage of spermatozoa motility was significantly decreased $(\mathrm{p}<0.05)$ in the oil extract treated animals.

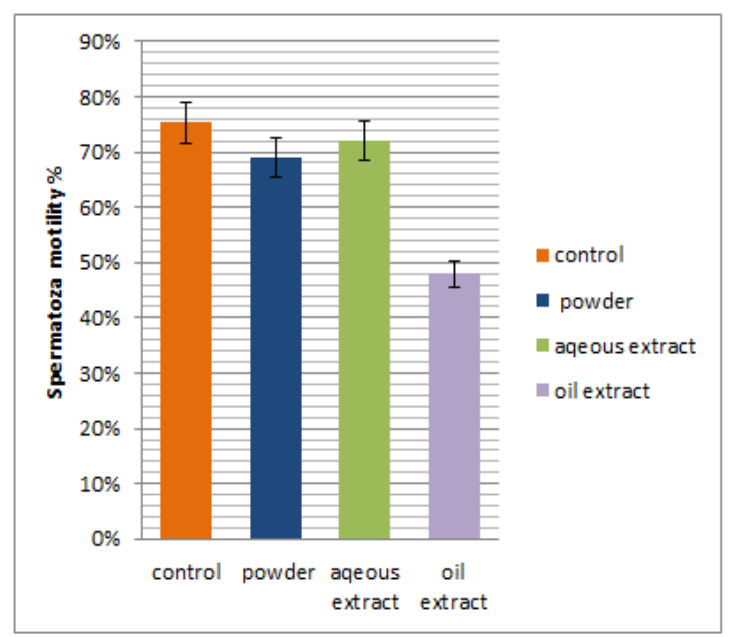

Fig. 6: Effects of the (powder, aqueous, and oil extracts) of fenugreek seeds on the mobility of spermatozoa after a 60 days treatment.

\section{Discussion}

Trigonella foenu-graecum has been widely used in folk medicine as an antihypertensive, anti-hypercholesterolemic, improving cardiac function in patients with coronary artery diseases, as hormonal replacement therapy in postmenopausal symptoms, and in male sexual dysfunction $(4,11,18)$.

In the first part of our study, we have examined the effect of fenugreek seeds different dosage forms (powder, aqueous and oil extracts) on sex hormonal levels in male rats.

Changes in the hormonal levels, showed a highly significant reduction of FSH level with the oily form treated group compared to the other comparative groups. While a significant reduction in LH hormone was clearly observed with all treated groups compared to the control one. This significant reduction in both FSH \& LH levels was accompanied with observed significant reduction in serum testosterone levels in rats administered either fenugreek seeds' powder or oily form compared to the control group.

In the year 2005, Grover $\boldsymbol{e t}$ al. ${ }^{23}$ revealed the importance of both FSH and LH hormones in the maturation of sprematoza and testosterone production. LH stimulates testosterone production from the interstitial cells of the testes (Leydig cells). While, FSH stimulates testicular growth and enhances the production of an androgen-binding protein by the Sertoli cells, which are a component of the testicular tubule necessary for sustaining the maturation of sperm cells. This protein causes high local concentrations of testosterone near the sperm, an essential factor in the development of normal spermatogenesis. Also, Sertoli cells secrete inhibin, a polypeptide, under the influence of androgens, which may help to locally regulate spermatogenesis ${ }^{23}$. Testosterone is the principle male hormone; it is synthesized by Leydig cells of testes from cholesterol $^{24}$.

This decrement of testosterone level may be due to the effects of saponin on serum cholesterol level, which is essential for testosterone synthesis by its action on the Leydig cells. Numerous studies reported that saponin lowers serum cholesterol level and hence affect testosterone production \& spermatogenesi $\mathrm{i}^{25}$.

These results agreed with our study findings where the significant reduction in both FSH \& LH levels was accompanied with a significant reduction in testosterone level in both powder and oily forms treated groups. In 2006, Kassem and his colleageus ${ }^{26}$ revealed 
that Trigonella foenum-graecum has decreased the plasma androgen concentration \& decreased the sperm count. These results agree with that of the present study that fenugreek decreased the sperm count and this may be due to the presence of steroidal oestrogen-like saponins. In contrast, some animal and human studies introduced Trigonella foenum-graecum extract as a food supplement to boost testosterone ${ }^{27 \& 28}$.

Although, aqueous extract of fenugreek exert significant reduction in LH level as well as the other forms, but testosterone level \& sperm count were significantly increased after the administration of the aqueous form. Therefore more investigations are needed in this field.

Considering the results, the amount of progesterone hormone was increased significantly in all experimental groups with a highly marked increase with the oily form compared to the other experimental groups. Progesterone increase can be ascribed to diosgenin compounds of fenugreek which act as progesterone precursor ${ }^{29}$.

On the other hand, estrogen level was significantly increased in oily form treated group with insignificant decrease in the aqueous form treated group compared to the control group. Moreover, the present study showed insignificant decrease in prolactin levels in all comparative groups compared to control one. Sperm motility and vitality were both decreased significantly following the administration of the powder \& oily forms.

Histological examination in both powder and aqueous dosage forms showed nearly normal appearance of the germinal cell population and tubules. Whereas, the oil form showed severe degeneration and disruption of the integrity of the tubules. Many tubules revealed multiple vacuolation and their germinal epithelium appeared dissociated from each other.

Moreover, sertoli cells were found completely destructed and replaced by swollen degenerated apoptotic cells in the oil dosage form. These results contradict another study that assessed the protective effect of fenugreek seeds extract after the administration of the anticancer drug cyclophosphamide on the testes. The study has revealed a release of antioxidants such as malondialdehyde (MDA) in the testes which counteracted the histological alteration such as appearance of irregular seminiferous tubules, reduction in the number of all spermatogenic cells, degeneration of Leydig cells and appearance of intertubular hemorrhage caused by cyclophosphamide ${ }^{29}$.

On the other hand, a study was conducted to assess feeding $30 \%$ of fenugreek powder for three months to New Zealand rabbits showed a significant reduction in testicular weight, sperm concentration and plasma androgen levels. The testicular weight and sperm concentration were both found lesser than the control by $25 \%$ and $47 \%$, respectively. Moreover, testosterone was lower by $65.8 \%$ in comparison to the control animals. Histopathological examination of the testes revealed a decrease in the number of seminiferous tubules along with mild thickening of the basement membrane and mild spermatogenesis hypoplasia in comparison to the control group ${ }^{30}$.

However, the elevation in sperm count in the aqueous extract treated group in te present study is in accordance with another study which was conducted to assess a new fenugreek extract. The study revealed an elevated level of free testosterone in blood up to $46 \%$ in $90 \%$ of the samples. Sperm count was improved in $85.4 \%$ of the study population as well as, sperm morphology with $14.6 \%{ }^{31}$.

On the other hand, a trial was conducted to assess the safety and efficacy of the glycoside portion of Trigonella foenumgraecum seeds on muscle anabolism, androgenic hormones, and body fat in healthy male after 8 weeks of treatment, with a resistance training program. Sixty healthy males were randomized for either the administration of a capsule of $300 \mathrm{mg}$, twice per day or the matching placebo. Serum testosterone (total and free) levels, muscle strength and repetitions to failure, metabolic markers for anabolic activity (serum creatinine and blood urea nitrogen), and \% body fat were assessed. The study has concluded a significant anabolic and androgenic activity as compared to the control ${ }^{32}$.

These study results agree with the present study, where sperm count was enhanced with fenugreek extract, particularly, the aqueous extract. In addition, the improvement in testosterone levels in male rats were also 
exhibited in the aqueous form only. All these findings, might be due to that the concentration of the steoidal saponins are less in the aqeous medium than that in the oily medium. In such a way, that also might explain that the oil form exhibited a devastating action on sperm motility, vitality, along with the testicular tissues compared to the control and the two other forms.

\section{Conclusion}

Trigonella foenum-graecum seeds showed a significant enhancement in sperm count and male hormonal function, particularly, the aqueous form. While the oil form was much

\section{REFERENCES}

1. J. Al-Asadi," Therapeutic Uses of Fenugreek (Trigonella foenum-graecum L.)". AJSIH, Special issue, 154-162 (2014).

2. M. Petruzzello, "Fenugreek herb", Britannica, (2017).

3. P. Zandi, S. Basu, lx. Cetzal, S. Khademi Chalaras, L. Bazrkar Khatibani and M. Kordrostami, "Fenugreek (Trigonella foenum-graecum L.): An Important Medicinal and Aromatic Crop", Active Ingredients from Aromatic and Medicinal Plants, IntechOpen,217-223 (2017).

4. S. Malhotra, "Fenugreek (Trigonella foenum-graecum L.). In: Genetic Resources, Chromosome Engineering, and Crop Improvement", J Med Plant Res, 801-846 (2011).

5. S.A. Wani and P. Kumar, "Fenugreek: A review on its nutraceutical properties and utilization in various food products", $\boldsymbol{J}$ Saudi Soc Agric Sci., 17, 97-106 (2018).

6. R. S. Pandian, C. V. Anuradha and P. Viswanathan, "Gastroprotective effect of fenugreek seeds (Trigonella foenum graecum) on experimental gastric ulcer in rats". J Ethnopharmacol, 81, 393-397 (2002).

7. B. Max, "This and That: The essential pharmacology of herbs and spices. Trends. Pharma Sci., 13(1), 15-20 (1992).

8. R.C. Garg, "Fenugreek", In: Nutraceuticals. Elsevier; 599-617 (2016). more intense in the damaging effect on both the sperm count, vitality and histological changes in the testicles. Further studies are recommended for assessing the main components responsible for such effects with the proper doses.

\section{Limitations}

The study was limited to assess the main ingredient involved in such an effect as well as the possible mechanisms justifying the fluctuation in hormonal levels and histological changes between the three different forms.

9. M. D. Bethesda, "Drugs and Lactation Database (LactMed)", USA: NLM 2021. (2016).

10. R.C. Gupta, R. Lall and A. Srivastava, "Introduction", In: Gupta RC, Lall R, Srivastava A, editors. Nutraceuticals (Second Edition). Academic Press; (2021).

11. S. Sreeja, V. S. Anju, "In vitro estrogenic activities of fenugreek Trigonella foenum graecum seeds", Indian J Med Res, 13, 814-819 (2013).

12. E. Steels, A. Rao and L. Vitetta , "Physiological Aspects of Male Libido Enhanced by Standardized Trigonella foenum-graecum Extract and Mineral Formulation: male libido enhanced by standardized trigonella foenum-graecum extract". Phytother Res, 5, 1294-3000 (2011).

13. Pubchem, "PubChem Compound Summary for CID 99474", Diosgenin. NCBI, (2021), Available from: https://pubchem.ncbi.nlm.nih.gov/compou nd/Diosgeni

14. I. Rasooli, "Bioactive compounds in phytomedicine". Croatia: Masa Vidovic, 218 (2011).

15. H. Benghuzzi, M. Tucci, R. Eckie and J. Hughes," The effects of sustained delivery of diosgenin on the adrenal gland of female rats" Biomed Sci Instrum,39,33540 (2003).

16. A. V. Sirotkin, R. Alexa, S. Alwasel and A.H. Harrath, "The phytoestrogen, diosgenin, directly stimulates ovarian cell 
functions in two farm animal species", Domest Anim Endocrinol, 69,35-41 (2019).

17. A. Rao, E. Steels, G. Beccaria, W. J. Inder and L. Vitetta," Influence of a Specialized Trigonella foenum-graecum Seed Extract (Libifem), on Testosterone, Estradiol and Sexual Function in Healthy Menstruating Women, a Randomised Placebo Controlled Study: libifem, influence on hormones and sexual function", Phytother Res, 8,1123-30 (2015).

18. A. Mansoori, S. Hosseini, M. Zilaee, R. Hormoznejad and M. Fathi, "Effect of fenugreek extract supplement on testosterone levels in male: A meta-analysis of clinical trials", Phytother Res, 34,1550-5 (2020).

19. S. Salhi, M. Fadli, L. Zidane and A. Douira, " Etudes floristique et ethnobotanique des plantes médicinales de la ville de Kénitra (Maroc)", Lazaroa, 23,31 (2011).

20. A.T. Farag, A. F. El-Aswad and N. A. Shaaban, "Assessment of reproductive toxicity of orally administered technical dimethoate in male mice", Reprod Toxicol, 23, 232-238 (2007).

21. WHO," WHO laboratory manual for the Examination and processing of human semen" In Geneva, Swittzerland: World Health Organization, 22-24. (5th ed) (2010).

22. G. Baril, "Institut national de la recherche agronomique (France), Station de physiologie de la reproduction, Manuel de formation pour l'insémination artificielle chez les ovins et les caprins. Rome": FAO; (1993).

23. A. Grover, C. E, Smith, M. Gregory, et al. "Effects of FSH receptor deletion on epididymal tubules and sperm morphology, numbers, and motility". Mol Reprod Dev, 72(2),135-144 (2005).

24. W. F. Ganong, "Review of Medical Physiology. 22nd Ed. Lange Medical Books/ McGraw-Hill Boston, Toronto, New Jersey, PP. 424-430 (2005).

25. K. E. Barrett, S. M. Barman, S. Boitano, and H. L. Brooks, "Ganong's Review of Medical Physiology. 23rd Ed.
(International Edition), Published by McGraw- Hill Companies. Inc. Printed in Singapore, Section IV, PP. 4024289(2010).

26. A. Kassem, A. Al-Aghbari, M. T. ALHabori and M. Al-Mamary, "Evaluation of the potential antifertility effect of fenugreek seeds in male and female rabbits", Contraception, 73, 301-306 (2006).

27. U. Aswar, S. L. Bodhankar, V. Mohan and P. A. Thakurdesai, "Effect of furostanol glycosides from Trigonella foenumgraecum on the reproductive system of male albino rats", Phytotherapy Research, 24(10), 1482-1488 (2010).

28. S. M. Nguyen, N. Ko Ko, A. S. Sattar, E. Gucuk Ipek and S.Ali, "Pulmonary embolism secondary to testosteroneenhancing herbal MANSOORI ET AL. 5 supplement use و" Cureus, 9(8), e1545 (2017).

29. A. Maheshwari, N. Verma, A. Swaroop, M. Bagchi, H.G. Preuss, K. Tiwari, et al. "Efficacy of Furosap TM , a novel Trigonella foenum-graecum seed extract, in Enhancing Testosterone Level and Improving Sperm Profile in Male Volunteers", Int J Med Sci, 14,58-66 (2017).

30. A. Kassem and M. Al-Mamary, "Original research article Evaluation of the potential antifertility effect of fenugreek seeds in male and female rabbits", Contraception, 73, 301-6 (2021).

31. K.C. Nagulapalli Venkata, A. Swaroop, D. Bagchi and A. Bishayee,"A small plant with big benefits: Fenugreek ( Trigonella foenum-graecum Linn.) for disease prevention and health promotion", Mol Nutr Food Res, 61, 243-54 (2017).

32. S. Wankhede, V. Mohan and P. Thakurdesai,"Beneficial effects of fenugreek glycoside supplementation in male subjects during resistance training: A randomized controlled pilot study", JSHS, 5, 176-82 (2016). 


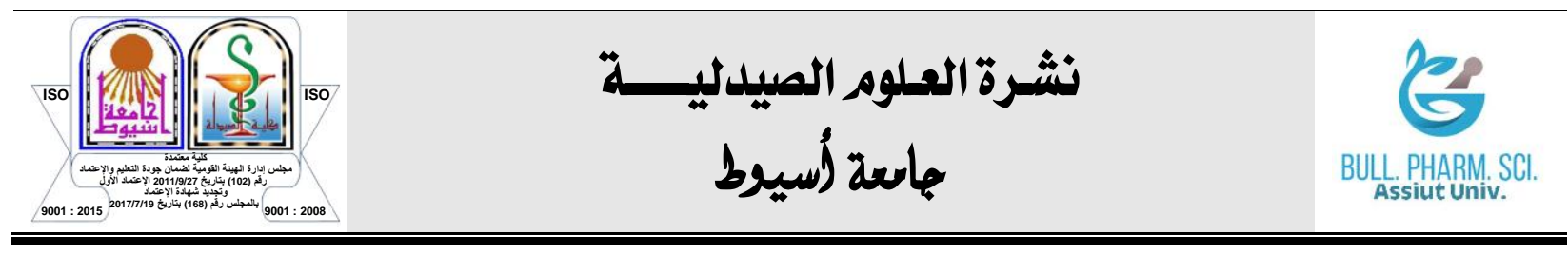

\section{دراسة مقارنة عن تأثير بذور نبات الحلبة ومستخلصيها المائي والزيتي على الجي الجئي الجهاز التناسلي لذكور الجرذان البيضاء}

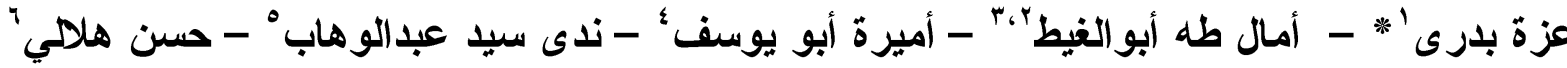

$$
\begin{aligned}
& \text { صيدلى بمديرية الشئون الصحية بأسيوط ، وزارة الصحة المصرية } \\
& \text { 'قسم الهستولوجى ، كلية الطب البشرى ، جامعة أسيوط ، مصر }
\end{aligned}
$$

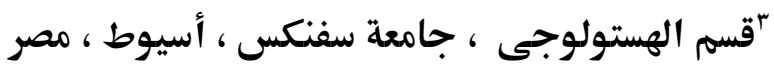

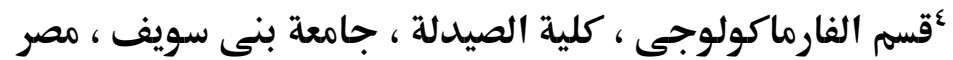

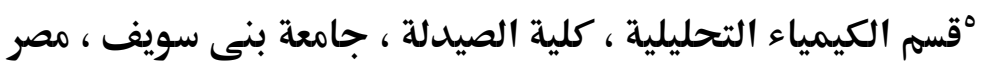

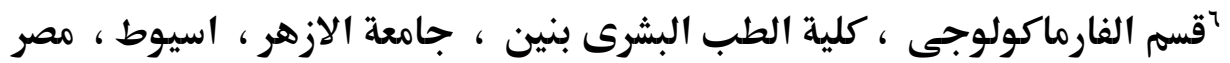

المقدمة: يعتبر نبات الحلبة أو Trigonella foenum-graecum معروف في الطب الشعبي في عـلاج الضعف الجنسي لدى كلا الجنسين. ومن المعروف أيضا أن بذور الحلبة غنية بالعديد من المكونات النشطة

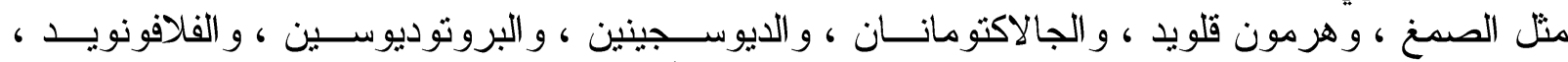

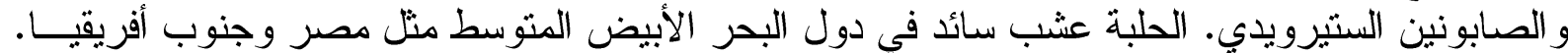

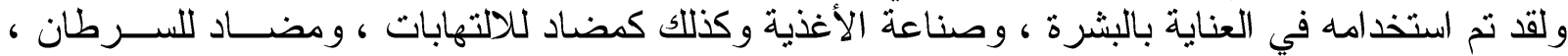

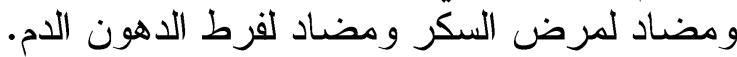

الأهداف: هدفت هذه الدر اسة إلى تقييم التأثير ات المحتملة لأشكال الحلبــة المختلفــة (مســحوق الحلبـــة ، مستخلصات مائية وزيتية) على الجهاز التناسلي للفكور باستخدام الجرذان البئ البيضاء.

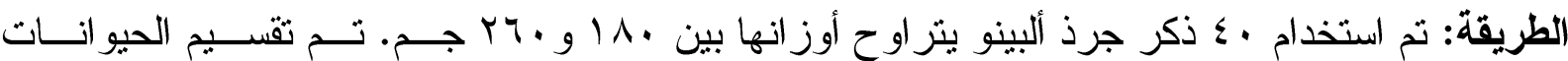

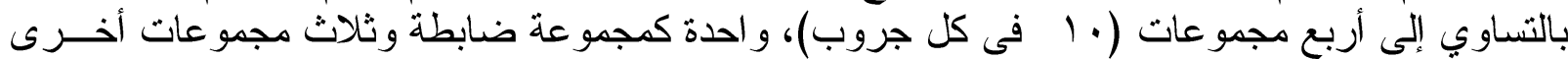

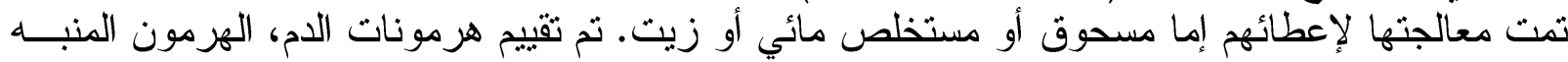

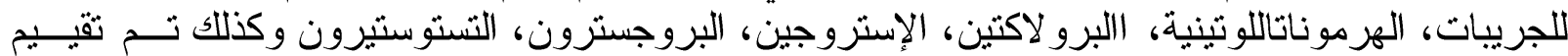

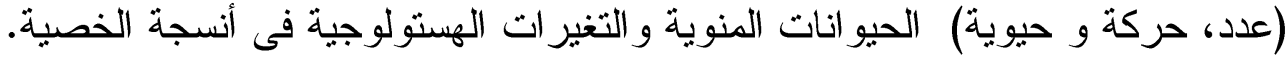

النتائج: انخفاض ملحوظ لهرمون FSH في الجرعة الزيتية مقارنة بالمجمو عات الأخرى. كما تم ملاحظة

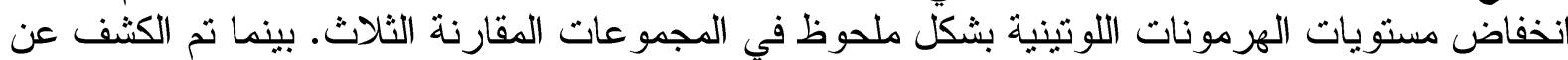

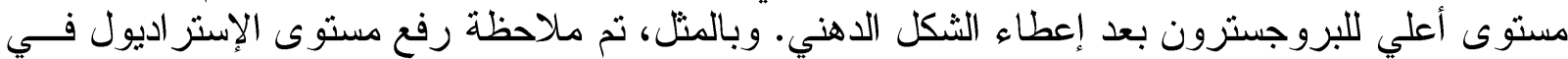

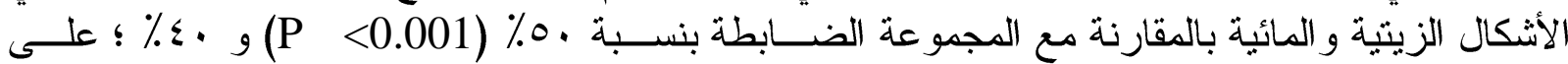

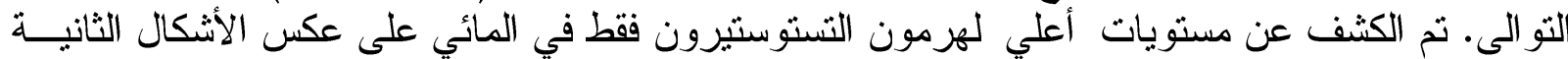

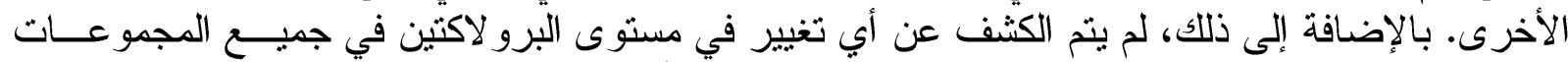

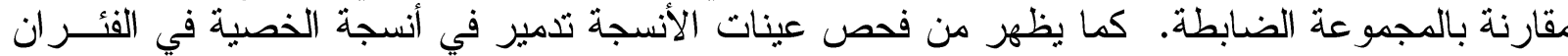

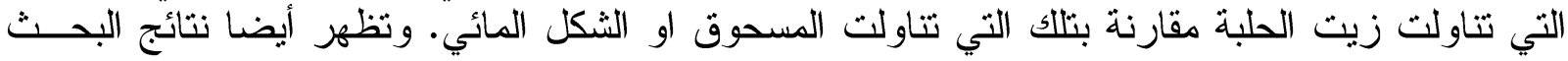




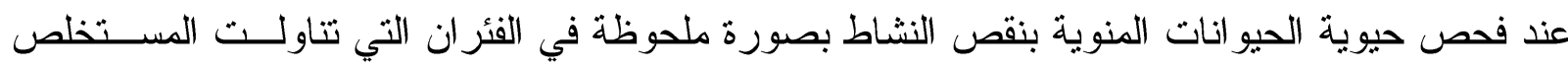
الزيتى ويليها التي تتاولت المسحوق عن تلك التي تتاولت الثنكل المائي.

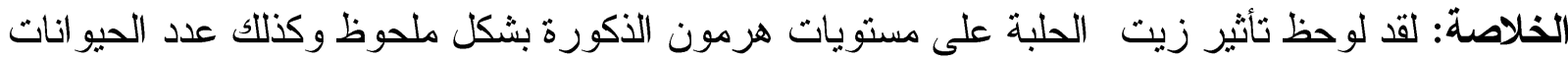

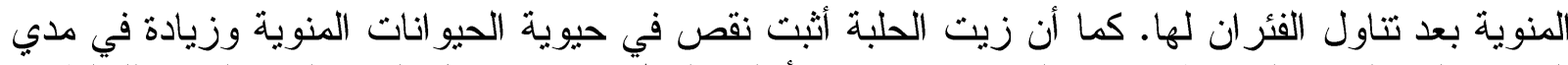
الضرر الذي لحق بالخصية بعد تتاوله. بينما تحسنت أغلب الوظائف بعد تتاول المستخلص المائي للحلبة. 